\title{
Practical Electronics as a Tool for Enhancing Physics Students' Interest in Learning the Concept of Electricity in Lagos, Nigeria.
}

Article History:

Received 16.03.2021

Received in revised form

28.11.2021

Accepted

Available online 01.03.2022

\author{
Jamiu Oluwadamilare Amusa ${ }^{1}$
}

The need to scale-up physics students' interest in learning the concept of electricity at the senior secondary school level has remained a concern for physics educators. This study examined the influence of practical electronics activities as an intervention towards raising the students' interest in learning electricity related topics in physics. A nonexperimental design of causal-comparative research type was adopted while multi-stage sampling procedure was used to select 280 senior secondary III (SS3) physics students from Education District II in Lagos State. A self-developed questionnaire titled "Students Interest Scale on Learning the Concept of Electricity (SIS-LCE)" was administered to capture the demographic profile of the students and their interest in learning the concept of electricity. The ordinal alpha reliability coefficient yielded a value of 0.88 . Descriptive statistics of mean and standard deviation were used in the analysis while independent Sample t-test was deployed to test the hypothesis at 0.05 significance level. Findings showed that students who engaged in practical electronics had higher interest in learning the concept of electricity than those who did not. Thus, the author recommends that practical electronics activities should be encouraged among physics students at the secondary school level.

(C) IJERE. All rights reserved

Keywords: Physics, practical electronics, students interest, electricity

\section{INTRODUCTION}

In the opening remarks of the Honourable Minister for Education, Malam Adamu Adamu, as contained in the forward page of the National Policy on Science and Technology Education, it was re-affirmed that science education is critical to the acquisition of technical and vocational skills which are veritable tools for driving national growth and development (FME, 2018). The so much desired scientific and technological independence towards building a self-reliant nation is hinged on the country's capacity to develop its physics education (Amusa, 2020). Science education is an effective instrument of empowering the citizenry to overcome poverty and limit the incidence of social vices due to joblessness arising from lack of skills among its productive workforce (FME, 2018). Prominent among the science education subjects at the senior secondary school level is physics. It is a compulsory subject for all science and technical oriented students beginning from senior secondary school 1(SSS1) to SSS3.

Going by the thematic approach of curriculum design at the secondary school level, physics as one of the physical science subjects is built on six distinct themes as shown in Table 1. The six themes and their corresponding topics are spread in a spiral arrangement from senior secondary 1 (SS1) to SS3. Theme 1(Interaction of Matter, Space and Time and Theme 2(Conservation principles) are generally classified as Mechanics while Theme IV (Field at rest and in Motion) is commonly known as the concept of electricity. The fifth theme (Energy Quantization and Duality of Matter) is best known as nuclear physics while the fourth theme deals with Waves and Optics (Amusa, 2019).

The fourth theme, Field at Rest and in Motion, contains all topics that relate to electricity, is the primary focus of this study. According to the breakdown of topics in one of the commonly used physics textbooks, the New School Physics for Senior Secondary Schools authored by M.W. Anyakoha, the following topics on electricity were considered prominent: Electric charges, Electric lines of force, Potential difference and electric current, Principle of production of electricity from a Dam, Electric Circuit, Ohm's law, Electric work done in a circuit, Electric force between point charges (Coulomb's law), Electric field intensity, Electric potential, Capacitors and Capacitance, Energy Stored in a capacitor, Production of continuous charges, Arrangement of cells and resistors, Resistivity and Conductivity, Galvanometer conversions, Principle of a potentiometer, Measurement of resistance by ammeter-voltmeter method, Conduction of electron through liquid (electrolysis), Conduction of electricity through gases, Electromagnetic field, Laws of electromagnetic induction, Power transmission, and Simple alternating circuits (Amusa, 2019; Anyakoha, 2016).

${ }^{1}$ Doctor, National Open University of Nigeria, jamusa@noun.edu.ng,orcid.org/0000-0002-4739-9632 
Table 1

Six Themes in the SSS Physics Curriculum and Spiral Arrangement of the Topics

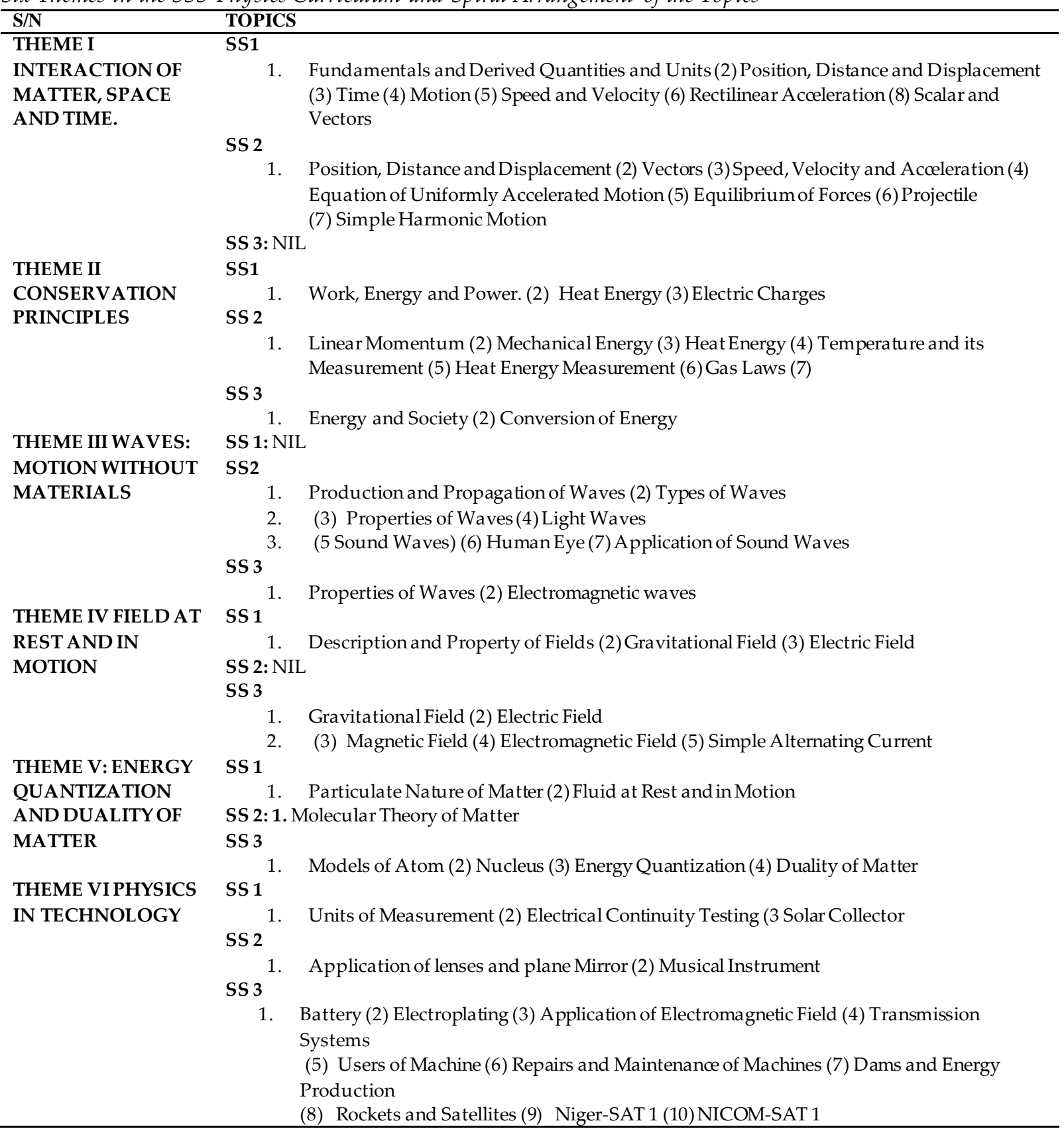

Source: Amusa (2019)

Electricity and Magnetism was considered as a very significant area of physics and science curricula at basic and post-basic level of education (Mbonyiryivuze, et. al., 2019). It was further noted that this branch of physics offers tremendous opportunities for practical investigation, knowledge demonstration and understanding for young science students as it relates to some activities of everyday life. However, it has been reported that physics students are having problems in their conceptual understanding of the topics that relates to electricity and magnetism (Mbonyiryivuze, et. al., 2019). Research evidences have shown instances where students obtained high scores on some topics in physics without commensurate conceptual understanding of such topics. (Wieman \& Perkins, 2005; Muise, 2015; Von Korff, et al., 2016; Hussain, et. al., 2012). Further findings revealed that students memorized teacher's problem-solving algorithms and several mathematical formulae without understanding the fundamental concepts and principles of such area of knowledge (Osborne, et. al., 2004; Uwizeyimana, et. al., 2018) Meaningful learning is not by memorizing mathematical formulae and the theoretical content of physics. Rather, it is acquired by developing students conceptual understanding and problem-solving skills that will enable them connect physics knowledge with their 
immediate environment. Hence, teaching physics concepts such as electricity requires this type of consideration. Unfortunately, most of the teaching and learning process in the science classroom are always rendered through the traditional lecture methods which lacks the required practical consideration.

The challenges of learning physics at the secondary school level is not restricted to the concept of electricity. Research literatures are inundated with studies on the challenges militating against the effective teaching and learning of physics at the secondary school. While Samela (2010) identified lower level preparation, weak mathematical background, inadequate teacher qualification and poor pedagogical content knowledge, Owolabi and Oginni (2013) emphasized the challenge of inappropriate teaching methods. According to Erinosho (2013), students perceived physics as difficult, abstract and theoretical. Amusa (2019) posited that the average coefficient of difficulty of topics under the themes "Physics in Technology", "Energy Quantization and Duality of Matter" are 0.77 and 0.55 respectively. This translate into $77 \%$ and $85 \%$ difficulty level accordingly.

In a study titled Diagnosing and Remediating Students Perceived Difficult Topics in Secondary School Physics, Amusa (2019) noted that the average coefficient of difficulty computed for topics under the theme "Field at Rest and in Motion", which deals with contents on electricity is 0.68 . This represent $68 \%$ difficulty level. Similarly, the West African Examinations Council's Chief Examiner's Report for the year 2019 showed that physics candidates had problems with questions on static electricity. Students' interest in learning topics on electricity is generally low due to its perceived difficulty level. This perception is premised on the reasons that the topics are too mathematical, lack of relevant apparatus for practical purposes and poor teacher's explanation of the topic (Amusa 2019). Mikovic et. al (2012) noted that students often experienced difficulties in learning electricity and magnetism related concepts due to their abstract and complex nature.

In a comprehensive review carried out by Mbonyiryivuze, et. al., (2019) on the series of test instruments deployed to assess students' conceptual understanding of topics on electricity, research instruments such as The Conceptual Survey of Electricity and Magnetism (CSEM), Determining and Interpreting Resistive Electric Circuit Concepts Tests (DIRECT), The Electrical Current Conceptual Tests (ECCT) and Parallel Circuit Conceptual Understanding Test (PCCUT) were developed to measure students' knowledge about electricity and magnetism, students' understanding of a variety of DC resistive electric circuits concepts, 10th-grade students' understanding of electric current and students' conceptual understanding of parallel resistors respectively (Mbonyiryivuze, et. al. 2019). The review revealed that students' interest in electricity is very weak due to their poor conceptual understanding of basic electricity concepts. In some instances, it was discovered that the physics tutors also have difficulties in teaching these topics (Kanamugire 2019). These multiple challenges culminate into weakening the students' interest in learning the concept of electricity. Ertmer and Newby (2013) therefore opined that, learners should be made to see things based on their own conceptualization through a more learner-centred strategy of knowledge dissemination. In view of the students' state of mind about the concept of electricity, it becomes imperative to devise a strategy of raising student's interest on this important concept of physics. One strategy that is currently being put to test is the introduction of practical electronics as an extra-curricular activity to raise the students' interest towards learning electricity.

According to Atsumbe, et. al. (2018), electronics is a branch of physics (science and technology) which deals with the study of the flow and control of electrons in electrical circuits and their corresponding behaviour and effects in vacuums, gases, and semiconductors. It is also described as applied physics (Engineering) that deal with the design and application of devices, usually, circuit electronics, whose operation depends on the flow of electrons for generation, transmission, reception, storage of information, among others. This information may consist of voice or music such as a radio receiver, an image on a television screen, or numbers or other data on a computer (https://physicsabout.com/modern-physics/electronics/). Some of the common branches of electronics include Analog electronics, Digital Electronics, Industrial Electronics, Microelectronics, Optoelectronics, Circuit Design and, power electronics among others. Due to its complexity, some fractions of its elementary contents were extracted to develop the Basic Electronics curriculum for Nigeria secondary school students in the technical colleges. Going by the assertions of Nigerian Educational Research and Development Council (NERDC), some of the cardinal objectives of Basic Electronics as a distinct subject at the secondary school level are to provide a foundation for creativity and technological development, stimulate, develop and enhance entrepreneurial skills among students in the field of electronics (NERDC, 2007). In 
Nigeria, Basic Electronics curriculum and the conduct of its examination is under the control of National Board of Technical Education (NBTE).

Practical electronics as implied in this study refers to the hand-on-activities through which students are exposed to design and construction of common electronic gadgets with minimal theoretical engagement. It is instructive to note that Physics practical on concepts of electricity is clearly different from practical electronics as it conceived in this study. While the former deals with recommended physics experiments on electricity such experimental verification of ohm's law, verification of a resistance of a given wire, determination of the value of current and voltage flowing in a closed circuit, the latter is about the design and construction of functional domestic or office electrical gadgets. Such gadgets include Burglar Alarm Circuit (BAC), Automatic Light Switch (ALS), Gas Leakage Detector (GLD), Mosquito Repellant Circuit (MRC), LCD Display Circuit among several others. Physics practical activities on electricity are stipulated in the senior secondary physics curriculum and are meant to be part of WAEC and NECO examination during the students' terminal examination. On the other hand, the practical electronics under review in this study are non-examinable extracurricular activities designed to scale-up the interest of the students towards the study of electricity. It becomes duty bound on the physics teachers to link up the student's activities in electronic practical to their understanding of electricity in physics.

As a practical based strategy, the study is premised on the theory of constructivism as advocated by Vygotsky (1978). Constructivism is an epistemological view of knowledge construction rather than knowledge transmission and recording of information conveyed by others as often experienced in a traditional lecture method. The theory contends that learners have to construct their own knowledge individually or collectively during social interaction. Students develop knowledge through an active construction process, not through the passive reception of information. Learning in constructivism, according to Kerka (1997) is facilitated through the design of classroom activities that guide students to work collaboratively with others, set their own sequences and pace of work, and actively engage in problem solving and critical thinking. This is the major significance of hands-on practical exercise. One of the philosophical understanding in practical electronics strategy is that it ensures students see and feel the real application of this branch of physics in their daily activities. It becomes more captivating for the students when they participate actively in the design and production of such electronic gadgets towards solving a given problem.

The practical electronic strategy is not without cost implications. This is because the components for the production of any desired electronics gadget are not readily available in the school laboratory. Hence, it becomes imperative to consider the socio-economic implications on the school and the students who may have to pay to access the required components for the exercise. One of the several challenges that bedeviled the functionalities of practical activities in the regular physics classroom is poor funding. Physics laboratories in most of the public and some of the privately-owned secondary schools are without relevant apparatus and equipment. For the practical electronics to be successful as an extra-curricular activity, it requires some level of minimal funding either by the owners of the school or the parents of the physics students who will ultimately benefit immensely from the exercise. Without doubt, the student's socio-economic status becomes an essential factor when it comes to the matter of payment to access an educational experience. The OECD Programme for International Student Assessment(PISA) has shown that students' socioeconomic background has continually influence their opportunities to benefit from education and develop their skills (OECD, 2016). It was therefore advocated that important educational skills and experiences should be made sufficient and accessible for all students irrespective their background. Similar research findings established a significant relationship between socioeconomic status and academic achievement (Sirin, 2005). It was also noted that increase in socioeconomic status, which is premised on the combination of parents' education level, working status, family income, home opportunities of students and others factors, could enhance change in academic achievement. Parents with higher educational levels, which in so many instances translate into higher family income and consequently, higher socioeconomic status, are known for having higher academic expectations from their wards (Abu Bakar, et. al., 2017). Such parents also attach greater importance to education and greater possibilities for presenting extra opportunities for the children. Hence, the readiness to pay for electronic practical may not be burdensome for such students.

The few known secondary schools that engaged their students in practical electronics either through extra-curricular activities or as a trade subject in entrepreneurship studies often task the students on payments for electronics components that will be used for the construction of a chosen gadget. Some of the common 
practical electronic activities that have been carried out are highlighted in Table 2. The components are available for sale in some of the electronics parts market in Mushin, Oshodi and Alaba areas of Lagos state.

Table 2

Project Titles, Components and Usefulness

\begin{tabular}{|c|c|c|c|}
\hline S/N & Titleof Design & Electrical Components & Usefulness \\
\hline 1 & $\begin{array}{l}\text { GasLeakage } \\
\text { Censor }\end{array}$ & 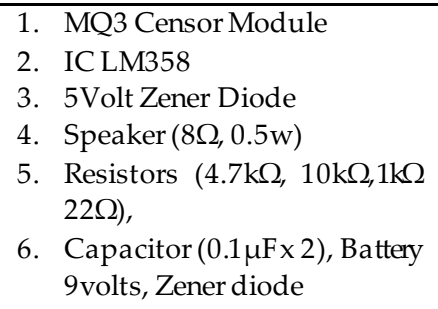 & $\begin{array}{l}\text { This electronic device is used to sense the presence of hazardous } \\
\text { gas at home, Service station, cars etc. The sensor is attached to an } \\
\text { alarm circuit to give alert to the operator through a buzzer sound } \\
\text { in the area where the gas leakage is occurring. The gas sensor is } \\
\text { also used to detect cigarette smoke, toxicgasses and combustible } \\
\text { propane }\end{array}$ \\
\hline 2 & $\begin{array}{l}\text { Mosquito } \\
\text { Repellant } \\
\text { Circuit }\end{array}$ & $\begin{array}{l}\text { 1. } 555 \text { timer } \mathrm{IC} \\
\text { 2. } \text { Buzzer } \\
\text { 3. } \text { Resistor } 1 \mathrm{k} \Omega \text { and } 1.3 \mathrm{k} \Omega \\
\text { 4. } \text { Variable Resistor } 10 \mathrm{k} \Omega \\
\text { 5. Capacitor } 0.01 \mu \mathrm{F} \\
\text { 6. } \\
\text { 7. } \text { Battery } 9 \mathrm{Volts} \\
\text { Board and Connecting wire }\end{array}$ & $\begin{array}{l}\text { This device uses the principle of ultrasound with a frequency } \\
\text { higher than } 20 \mathrm{KHz} \text {. Sound with frequency higher than } 20 \mathrm{KHz} \text { is } \\
\text { termed ultrasound. Sound between the frequency range of } 20 \mathrm{KHz} \\
\text { and } 20 \mathrm{~Hz} \text { is audible to human ear. The Female mosquitoes that } \\
\text { transmit malaria parasite tend to avoid ultrasound in the range of } \\
20 \mathrm{KHz} \text { and } 40 \mathrm{KHz} \text { after breeding, the same sound range } \\
\text { produced by the male counterpart. This principle is used to repel } \\
\text { the female mosquito when the ultrasound of the specified range } \\
\text { is produced. }\end{array}$ \\
\hline 3 & $\begin{array}{l}\text { Automatic } \\
\text { Switch }\end{array}$ & $\begin{array}{l}\text { 1. Resistor: } 100 \mathrm{k} \Omega, 2.2 \mathrm{~m} \Omega \\
\text { 2. Capacitor: } 0.1 \mu \mathrm{F} \\
\text { 3. Transformer: } 12 \text { volts } \\
\text { 4. Diode: } 1 \mathrm{~N} 4007 \\
\text { 5. IC } 4049, \mathrm{IC} 4093, \mathrm{IC} 555 \\
\text { 6. Relay: } 12 \text { volts }\end{array}$ & $\begin{array}{l}\text { The device makes use of phototransistor to switch on when it } \\
\text { senses darkness and switch off when it senses daylight. }\end{array}$ \\
\hline 4 & $\begin{array}{l}\text { Burglar Alarm } \\
\text { Circuit }\end{array}$ & $\begin{array}{l}\text { 1. PIRSensor } \\
\text { 2. UM } 3561 \mathrm{IC} \\
\text { 3. Resistor } 220 \mathrm{k} \Omega \text { and } 10 \mathrm{k} \Omega \\
\text { 4. Transistor } \mathrm{BC} 547 \\
\text { 5. Speaker } 8 \Omega \\
\text { 6. 9volt Battery \& Connector } \\
\text { 7. Board and connecting wire }\end{array}$ & $\begin{array}{l}\text { This device is an essential part of home security systems. The PIR } \\
\text { sensor is used to produce Police Siren after detecting any strange } \\
\text { movement. It can also produce other type of sound such as gun } \\
\text { shot, fire service siren etc. }\end{array}$ \\
\hline 5 & $\begin{array}{l}\text { LED Display } \\
\text { Circuit }\end{array}$ & $\begin{array}{l}\text { 1. Resistors: } 1 \mathrm{k} \Omega, 33 \mathrm{k} \Omega, 100 \mathrm{k} \Omega \\
\text { 2. Capacitor: } 4.7 \mu \mathrm{F}, 25 \mathrm{~V}, 0.1 \mu \mathrm{F} \\
\text { 3. IC555 } \\
\text { 4. Transistor BT } 169 \\
\text { 5. Transformer: } 12 \text { volts }\end{array}$ & $\begin{array}{l}\text { This device shows a LED-light display of words formed on the } \\
\text { board. It is used for advertorial purposes. It is configured around } \\
\text { a standard IC } 555 \text { chaser circuit, where the IC transmit the } \\
\text { required sequence. }\end{array}$ \\
\hline
\end{tabular}

It must be pointed out that practical electronics (Radio, Television and Electronic Work) is among the thirty-four (34) trade subjects available for the science students at the senior secondary school level. One of the trade subjects must be chosen in a compulsory subject called Entrepreneurship Studies as a way of fulfilling Federal Government requirement before passing out of secondary school in Nigeria. It is however unfortunate that most secondary schools, both public and private, have not done enough to encourage their students towards offering electronics as a trade subject. Perhaps, the socio-economic demand of the trade subject may be too much to bear. However, the benefits entrenched in the subject for the technological development of the nation outweigh its cost. The nexus between the concept of electricity and practical electronics is not in doubt. The main task ahead of physics educators therefore, is to explore how to drive the interest of physics students towards improving the learning of the concept of electricity.

\section{Purpose of the Study}

The main purpose of this study is to deploy practical electronics as an extra-curricular activity to raise the interest of senior secondary students in the learning of concept of electricity in physics. Other specific objectives are

1. To determine how practical electronics will influence physics students' interest in learning the concept of electricity 
2. To ascertain the influence of socio-economic status on students' the participation in the practical electronic activities.

\section{Research Hypotheses}

1. Practical electronics will not have significant influence on physics students' interest in learning the concept of electricity

2. Socioeconomic status will not have significant influence on physics students' interest in learning the concept of electricity

\section{Methods}

This study adopted a non-experimental design of causal-comparative research type. The target population was the senior secondary school III (SSS3) physics students in Lagos State, Nigeria. Multi-stage sampling procedure was adopted to select physics students who completed learning on all the topics on electricity. First, one Education District out of the six (6) Districts in Lagos State was selected through simple random sampling technique. The second stage yielded the selection of Ikorodu Local Government Area (LGA) out of the three (3) LGAs that formed District II. In the third sampling stage, purposive sampling technique was adopted for the selection of two groups of physics students. The first group was made up of 140 physics students who have not only completed the learning of topics on electricity, but also have the exposure to practical electronics during the school extra-curricular activities. The second group featured the selection of 140 physics students who do not have exposure to practical electronics but completed the learning of topics on electricity. The participants were made up of 152 male and 128 female physics students with an average age of sixteen years. The cosmopolitan nature of Lagos State made it possible to have students across major ethnic groups in Nigeria Hausa, Igbo and Yoruba. Hence, the subjects of the study were highly homogenous. On the whole, a total of 280 physics students were selected as the subjects of the study.

A self-developed questionnaire titled "STUDENTS INTEREST SCALE ON LEARNING THE CONCEPT OF ELECTRICITY (SIS-LCE)" was administered to capture relevant data. The questionnaire was classified into section A and B. Section A contained items on demographic profile of the students while section B elicited information to determine the level of students' interest in learning the concept of electricity. The ten (10) items in section B were developed on a four-point Likert scale of Strongly Agree-4, Agree -3, Disagree - 2 and Strongly Disagree - 1 . The questionnaire was subjected to face and content validation by three experts in measurement and evaluation. The reliability coefficient was ascertained using ordinal alpha after it was trial tested on 50 physics students who did not participate in the main study. The reliability coefficient computed was 0.88 . Descriptive statistics of mean and standard deviation was used to respond to the research questions while independent Sample t-test was used for the test the hypothesis at 0.05 significance level.

\section{Results and Discussion}

Hypothesis 1: Practical electronics will not have significant influence on physics students' interest in learning the concept of electricity.

In testing this hypothesis, responses of students who engaged in practical electronics activities and those that did not with respect to their interest in learning the concept of electricity were conducted using independent sample t-test. This statistical tool was apt because the dataset followed a normal distribution, with the values of skewness and kurtosis fell within the normal range of -2.58 to +2.58 . The results are presented in Tables $1 \mathrm{a}$ and $1 \mathrm{~b}$ as follows: 
Table 1a: Descriptive statistics of practical electronics activities on physics students' interest in learning electricity.

\begin{tabular}{|c|c|c|c|c|}
\hline & $\begin{array}{c}\text { Practical } \\
\text { Activities (PEA) }\end{array}$ & $\mathbf{N}$ & Mean & $\begin{array}{c}\text { Std. } \\
\text { Deviation }\end{array}$ \\
\hline \multirow[t]{2}{*}{ Interest in Learning Electricity } & Engaged in PEA & 143 & 32.47 & 3.73 \\
\hline & Not Engaged in PEA & 137 & 26.47 & 5.64 \\
\hline
\end{tabular}

Table 1b. Independent sample t-test of practical electronics activities on physics students' interest in learning electricity.

\begin{tabular}{|c|c|c|c|c|}
\hline & & & \multicolumn{2}{|c|}{ Interest in Learning Electricity } \\
\hline & & & Equal variances assumed & $\begin{array}{l}\text { Equal variances } \\
\text { not assumed }\end{array}$ \\
\hline \multirow{2}{*}{$\begin{array}{l}\text { Levene's Test for Equality } \\
\text { of Variances }\end{array}$} & $\mathrm{F}$ & & 23.67 & \\
\hline & Sig. & & 0.00 & \\
\hline \multirow{7}{*}{$\begin{array}{l}\text { t-test for Equality of } \\
\text { Means }\end{array}$} & $\mathrm{t}$ & & 10.54 & 10.45 \\
\hline & df & & 278 & 234.44 \\
\hline & Sig. (2-tailed) & & 0.00 & 0.00 \\
\hline & Mean Difference & & 6.00 & 6.00 \\
\hline & Std. Error Difference & & 0.57 & 0.57 \\
\hline & $\begin{array}{l}95 \% \text { Confidence Interval of the } \\
\text { Difference }\end{array}$ & Lower & 4.88 & 4.87 \\
\hline & & Upper & 7.12 & 7.13 \\
\hline
\end{tabular}

Table 1a showed the descriptive statistics of students engaged with practical electronics activities and those that did not with respect to their interest in learning the concept of electricity. It was remarked that performance of students engaged with practical electronics activities had ( $\bar{X}=32.47, \mathrm{SD}=3.73$ ) while those who did not had $(\bar{X}=26.47, S D=5.64)$. This result implies that on the average, students who engaged in practical electronics activities showed more interest in learning the concept of electricity better than their counterparts who did not engage in the practical electronics activities. Moreover, the mean difference was further confirmed using independent samplet-test (see Table $1 \mathrm{~b}$ ). The statistics showed that the mean difference was statistically significant $(\mathrm{t}=10.54, \mathrm{df}=278, \mathrm{p}=0.00$ (i.e. $\mathrm{p}<0.05)$ ). Consequently, the null hypothesis which stated that practical electronics will not have significant influence on physics students' interest in learning the concept of electricity was therefore rejected. This implies that the students who engaged with practical electronics activities showed more interest in learning the concept of electricity better than their counterparts who did not engage in the practical electronics activities. This finding is in agreement with the position of Adesoji and Olatubosun (2008) and Buthelezi (2012), who argued that students' academic performance in physics becomes better when they are able to recall what was seen and touched during practical session than what was merely mentioned in the classroom. Similarly, Odunbunmi and Adigun (1991) as cited in Lee and Sulaiman (2018), strongly advocated practical activities in science for weaker students as against the predominant use of lecture method.

Engagement in practical electronic activities afford the students the opportunities to handle components like resistors, capacitors, transistor, diodes, transformer, integrated circuits etc. The students had life experience of circuit designing, soldering of relevant components in given circuit board, and were able to take the readings on the components either through colour codes or with the aid of their multimeter. The students' understanding of transformer has gone beyond the large size step-down transformer on the streets of their communities to include the small-size components that can be packaged in a pocket-size pattress. Their abstract view of the above-mentioned components no longer exists. Hence, their interest and readiness to learn 
topics on electricity improved geometrically. Consequently, this would encourage them to attempt electricity related questions in any of their external examinations such as WAEC, NECO and UTME.

Hypothesis 2:

Physics students' socioeconomic status will not have significant influence on their interest in learning the concept of electricity.

In testing this hypothesis, obtained data for parents' socio-economic status of the students based on their interest in learning the concept of electricity were conducted using one-way analysis of variance (ANOVA).

Tables $2 \mathrm{a}, 2 \mathrm{~b}$ and Figure 1 presented the statistics.

Table 2a: Descriptive statistics of socio-economic status on physics students' interest in learning electricity

\begin{tabular}{lllcl}
\hline SES & N & Mean & Std. Deviation & Std. Error \\
\hline ow & 0 & 28.81 & 5.89 & 0.66 \\
Moderate & 118 & 28.96 & 5.20 & 0.48 \\
High & 82 & 31.06 & 5.73 & 0.63 \\
\hline
\end{tabular}

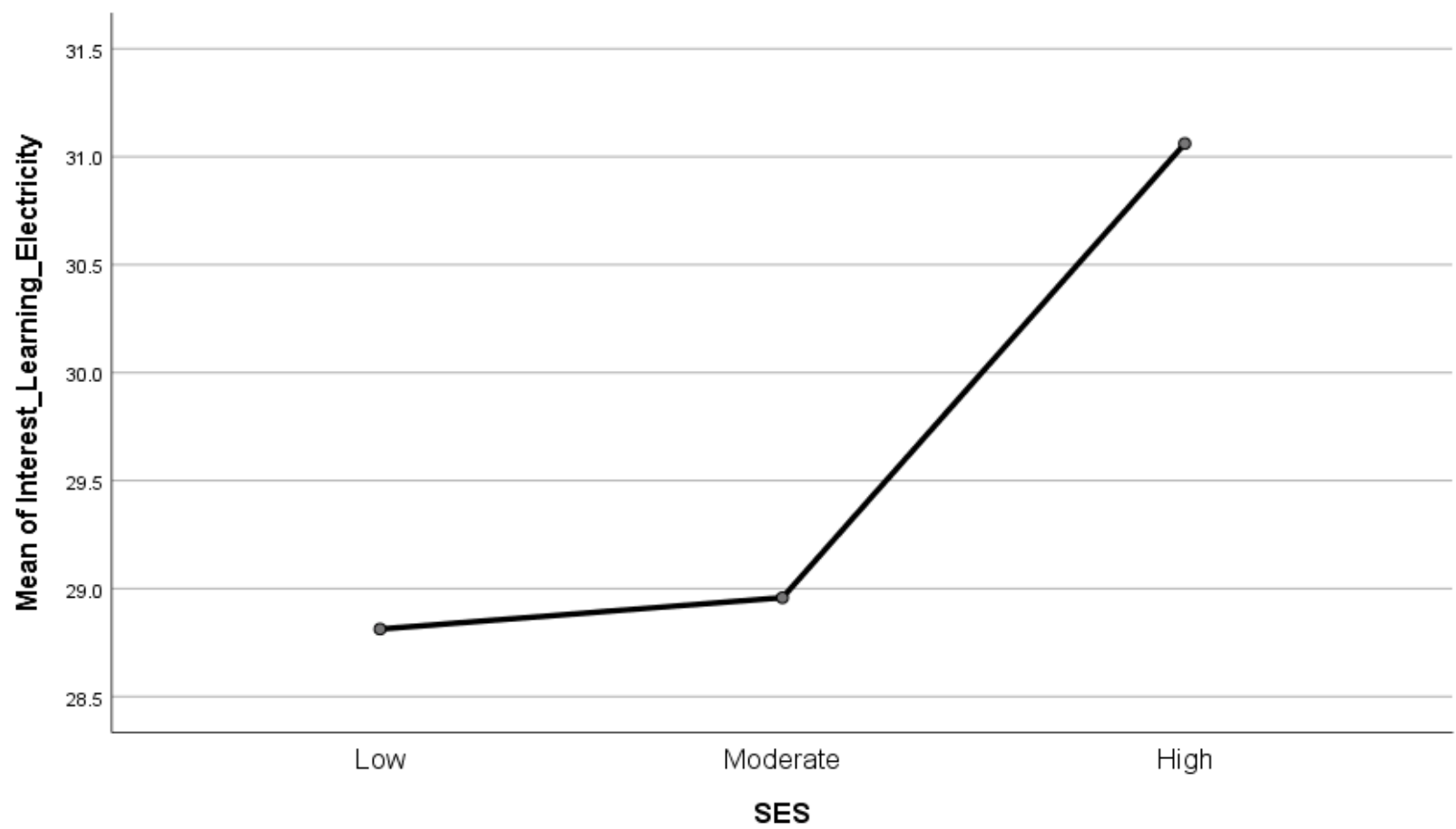

Figure 1: Mean Plot of socio-economic status on physics students' interest in learning electricity

Table 2b: Analysis of Variance of socio-economic status on physics students' interest in learning electricity

\begin{tabular}{lclccc}
\hline & Sum of Squares & df & Mean Square & F & Sig. \\
\hline Between Groups & 272.04 & 2 & 136.02 & 4.40 & 0.01 \\
Within Groups & 8555.67 & 277 & 30.89 & & \\
Total & 8827.71 & 279 & & & \\
\hline
\end{tabular}

Table 2a showed the estimated means of socio-economic status on physics students' interest in learning electricity. The table revealed that students from high socio-economic status had highest mean score of $\left(\bar{x}^{\bar{x}}=\right.$ 31.06, Sd = 5.73), followed by moderate with $\left({ }^{x}=28.96, \mathrm{Sd}=5.20\right)$ and low with $(\bar{x}=28.81, \mathrm{Sd}=5.89)$ respectively. The table remarked that students from high socio-economic status had the highest interest in the learning the concept of electricity, followed by moderate and those from low socio-economic status. This result was further verified using the mean plot (see figure 1). Furthermore, the observed mean difference was examined using analysis of variance. Table $2 b$ showed that there is statistically significant difference in socio- 
economic status on physics students' interest in learning electricity with $(\mathrm{F}(2,277)=4.40, \mathrm{p}=0.01$ (i.e. $\mathrm{p}<0.05))$. Therefore, the hypothesis which stated that " physics students' socioeconomic status will not have significant influence on their interest in learning the concept of electricity" was rejected. More importantly, since the difference is significant, assessing where the observed significance lies is inevitable. This feat was achieved using pair-wise comparison of sidak method. The result is presented in Table $2 \mathrm{c}$ as follows:

Table 2c. Pairwise comparison of socio-economic status on physics students' interest in learning electricity

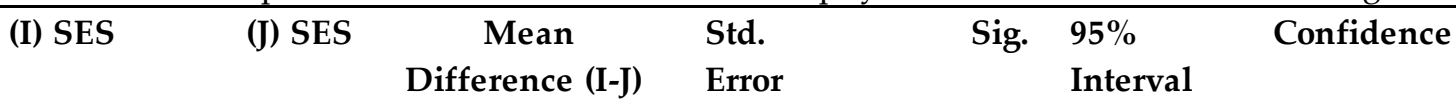

\begin{tabular}{lllllll}
\hline \multirow{2}{*}{ Low } & & & & \multicolumn{2}{c}{ Lower Bound } & Upper Bound \\
& Moderate & -0.15 & 0.81 & 0.90 & -2.08 & 1.79 \\
Moderate & High & $-2.25^{*}$ & 0.87 & 0.03 & -4.35 & -0.15 \\
& Low & 0.15 & 0.81 & 0.90 & -1.79 & 2.08 \\
& High & $-2.10^{*}$ & 0.80 & 0.03 & -4.02 & -0.18 \\
& Low & $2.25^{*}$ & 0.87 & 0.03 & 0.15 & 4.35 \\
& Moderate & $2.10^{*}$ & 0.80 & 0.03 & 0.18 & 4.02 \\
\hline
\end{tabular}

* The mean difference is significant at the 0.05 level.

Table 2c showed the pairwise comparisons of where the significant effect of socio-economic status on physics students' interest in learning electricity lies. The result remarked that students from low SES did not significantly show interest in the learning of electricity than their counterpart from moderate and high SES with (mean diff $=0.15, p>0.05(0.90)$ ). Furthermore, the table showed that students from high and moderate SES jointly significantly showed more interest in the learning of electricity than their counterpart from low SES with (mean diff $=2.25, \mathrm{p}<0.05(0.03)$; mean diff $=2.10, \mathrm{p}<0.05(0.03)$ ). The result implies that students from both high and moderate SES had the required resources to procure the relevant components that enabled them engaged in practical electronics activities which in turn enhances their interest in the learning of concept of electricity. The finding of this study is similar and consistent with the position of Suna et. al, (2020) who discovered that students with stronger socio-economic status had significantly higher academic achievement in language, mathematics and science test.

The associated cost in practical electronic activities has, undoubtedly, made it the exclusive right of the students from high socio-economic status. These class of students are majorly in the private schools. Hence, most government owned secondary schools which do not have adequate budgetary provision for practical activities, besides the practical electronics that is placed under extra-curricular activities, may completely be excluded from this important exposure to functional practical knowledge. Unfortunately, some high achieving students whose interest in learning the concept of electricity could also be improved, but belong to this category of students who were economically disadvantaged. Hence, the barrier to inclusiveness should be removed to enabled the best brains, irrespective of the socio-economic status, drive the desired national scientific and technological development.

\section{Conclusion}

One of the most effective methods of teaching physics at the secondary school level, with specific reference to the concept of electricity is through practical activities (Lee \& Sulaiman, 2018). Besides the statutory practical exercises recommended on the concept of electricity, practical electronics as extra-curricular activity through the school Junior Engineers, Technicians and Scientists (JETS) Club and other voluntary engagements, will certainly increase the students' interest in learning the concept of electricity as established in the study. Practical electronics activities will not only enhance the appropriate understanding of difficult concepts in electricity, it will further improve the students' problem-solving skills, stimulates permanence of knowledge and also ensure positive attitude towards physics in general. Students' ability to construct knowledge becomes easier with hands-on activity since they need to develop both the conceptual and procedural understanding of their practical engagement (Azar \& Şengülec, 2011). It was discovered that students who engaged in practical electronics have higher interest in learning the concept of electricity than other students who did not have such opportunity. The success of practical electronics or otherwise depends largely on the availability of relevant electronics components which in turn depends on the socio- 
economic status of the school and the students. Therefore, the socioeconomic status of students becomes a determining factor in measuring the level of their participation in practical electronics. It was discovered that physics students with high socioeconomic status have greater opportunity to engage in practical electronics over other students who occupied the moderate and low socioeconomic status. The study could not examine the implication of gender on the adoption of practical electronics for enhancing the learning of electricity. In addition, beside the limitations in finding the roles of school ownership (government and private) in the adoption of practical electronics, the study could not go beyond one state out of the thirty six (36) states in Nigeria

\section{Recommendation}

It is therefore recommended that:

1. Practical electronics activities should be encouraged among all physics students during the school extra-curricular activities and possibly through the school JETS' club.

2. Physics students should be encouraged to choose Practical Electronics (Radio, Television and Electronics) as the main Trade Subject in the Entrepreneurship Studies. This will afford them the opportunity to engage more in practical electronics activities.

3. Special budgetary allocation or project fund should be ensured for financing the procurement of relevant electronics components for the use of the students. This arrangement will take care of those students who are socioeconomically disadvantaged.

4. The mainstream/statutory physics practical activities should be reviewed to align with the current's reality of advancement in knowledge as obtained in other advanced society.

5. As a matter of government policy, there should be an annual secondary school science and technology exhibition where ground-breaking projects will be displayed and awards are giving out to outstanding schools. This will serve as motivation for the teachers in the physical sciences.

\section{REFERENCES}

Abu Bakar, N., Mamat, I., \& Mudassir, I. (2017). Influence of parental education on academic performance of secondary school students in Kuala Terengganu. International Journal of Academic Research in Business and Social Sciences, 7(8), 296-304.

Amusa, J.O. (2020). Appraisal of the physics education programme in the National Open University of Nigeria. Technical University of Varna Annual Journal, 4(1), 1-12. doi.org/10.29114/ajtuv.vol4.iss1.158.

Amusa, J.O. (2019). Diagnosing and Remediating Students' Perceived Difficult Topics in Secondary School Physics. Niger Delta Journal of Education. 2(2), $153-170$.

Anyakoha, M.W. (2016). New School Physics. Africana. Onitsha, Nigeria. First Publishers Plc

Azar, A., \& Şengülec, Ö. A. (2011). Computer-assisted and laboratory assisted teaching methods in physics teaching: The effect on student achievement and attitude towards physics. Eurasian Journal of Physics and Chemistry Education (Special Issue), 4350.

Buthelezi, N. (2012). Inside efforts to turn the tide on South Africa's poor Mathematics and Science performance. www.engineeringnews.co.za/article

Erinosho, S.Y. (2013). How do students perceive the difficulty of physics in secondary school? An Exploratory Study in Nigeria. International Journal for Cross-Disciplinary Subjects in Education (IJCDSE), 3(3), 1510-1515.

Ertmer, P. A., \& Newby, T. J. (2013). Behaviorism, cognitivism, constructivism: comparing critical features from an instructional design perspective. Performance Improvement Quarterly, 26(2), 43-71. https://doi.org/10.1002/piq.21143.

Mioković, Ž., Ganzberger, S., \& Radolić, V. (2012). Asssessment of the University of Osijek engineering students' conceptual understanding of electricity and magnetism. Tehnički vjesnik, 19(3), 563-572.

Hussain, N. H., Latiff, L. A., \& Yahaya, N. (2012). Alternative conception about open and short circuit concepts. Procedia - Social and Behavioral Sciences, 56, 466-473.

Kanamugire, C., Yadav, L. L., \& Mbonyiryivuze, A. (2019). Tutors' perceptions about science curriculum reforms and challenges for their implementation in teacher training colleges in Rwanda. African

Journal of Educational Studies in Mathematics and Sciences, 15(1), 101-116

Kerka, S. (1997). Constructivism, workplace learning, and vocational education. (ERIC Document Reproduction Service No. ED 407 573.)11-40. 
Lee, M, \& Sulaiman, F. (2018). The effectiveness of practical work in physics to improve students' academic performances. People: International Journal of Social Sciences, 3(3), 1404-1419.

Mbonyiryivuze, A., Yadav, L. L. \& Amadalo M. M. (2019). Students' conceptual understanding of electricity and magnetism and its implications: A review. African Journal of Educational Studies in Mathematics and Sciences 15 (2), 55 - 67

Muise, J. M. (2015). Using Peer Instruction to promote conceptual understanding in high school physics classes. Montana: Montana State University.

Nigerian Educational Research and Development Council (NERDC). (2007). Curriculum for basic electronics. Abuja. NERDC press.

Odubunmi, O., \& Balogun, T. A. (1991). The effect of laboratory and lecture teaching methods on cognitive achievement in integrated science. Journal of Research in Science Teaching, 28(3), 213-224. https://doi.org/10.1002/tea.3660280303

OECD (2016). PISA 2015 results (Volume I): Excellence and equity in education. Paris: OECD Publishing.

Osborne, J., Erduran, S., \& Simon, S. (2004). Enhancing the quality of argumentation in science classroom. Journal of Research in Science Teaching, 41(10), 994-1020

Owolabi, O. T. \& Oginni, O. I. (2013). Assessing the relative effectiveness of three teaching methods in the measurement of students' performance in Physics. International Journals of Material, Methods and Technologies, 1(8), 116-125.

Semela, T., (2010). Who is joining physics and why? Factors influencing the choice of physics among Ethiopian university students. International Journal of Environment E Science Education, 5(3), 319-340.

Şirin, S. R. (2005). Socioeconomic status and academic achievement: A meta-analytic review of research. Review of Educational Research, 75(3), 417-453.

Suna, H. E., Tanberkan, H., Gur, B. S., Perc, M., Ozer, M. (2020). Socioeconomic status and school type as predictors of academic achievement. Journal of Economy Culture and Society, 61, 41-64. https://doi.org/10.26650/JECS2020-0034

Von Korff, J., Archibeque, B., Gomez, K. A., Heckendorf, T., McKagan, S. B., C. Sayre, E., Sorell, L. (2016). Secondary analysis of teaching methods in introductory physics: A $50 \mathrm{k}$-student study. American Journal of Physics, 84(12), 969-974.

Vygotsky, L. S. (1978). Tool and symbol in child development. In M. Cole, V. John - Steiner, S.Scribner, \& E. Souberman (Eds). Mind in Society: The development of higher logical psychological processes.

Cambridge: Harvard University Press

Uwizeyimana, D., Yadav, L. L., Musengimana, T., \& Uwamahoro, J. (2018). The impact of teaching approaches on effective physics learning: an investigation conducted in five Secondary Schools in Rusizi District, Rwanda. Rwandan Journal of Education, 4(2), 2-14.

West African Examination Council (2019). Chief Examiner's Report on Physics Paper 2. https://www.waecgh.org/uploads/examinersReport/2019/Science19.pdf

Wieman, C., \& Perkins, K. (2005). Transforming physics education. Physics Today, 58(11). 